Vol. 3, No. 1 | January - June 2020

\title{
Experimental based Comparative Analysis and Characteristics of DC Series Motor by using Different Techniques
}

\author{
Mohsin Ali Koondhar ${ }^{1}$, Ali Asif Malak ${ }^{1}$, Masood Ali Koondhar ${ }^{1}$, Irfan Ali \\ Channa $^{2}$
}

\begin{abstract}
:
In this paper, distinct techniques of speed controlling of a Direct Current (DC) motor and its characteristics are discussed. The Direct Current (DC) motor has a wide range of speed control, which can be used in robots, drilling, cutting, and household applications due to affordable cost and low complexity of control configuration for speed and torque control. As DC Motors are considered as the best type of motors, in view of the speed control and speed regulation, numerous approaches are available to control the motor rotational speed. DC series motor control by using a resistive controller with and without a Programmable Logic Controller (PLC) is proposed. The motor voltage can be changed by inserting a resistor in series with DC motor. In this paper, through an experimental work armature resistive drive control technology and motor control PLC technology is used to control motor speed. PLC is used to control the resistance of the motor, thereby reducing driving voltage to change the speed. The results confirm the authentic efficiency of the proposed method of controlling motor speed.
\end{abstract}

Keywords: DC Series Motor, PLC, Torque, Resistive controller.

\section{Introduction}

The DC drives are used in rolling, wine winders, cranes, paper mills, machine tools, printing press, and textile mills, etc. DC motors have irregular essentials and used largely in uncertain speed. DC motor can produce immense origin torque and it is still achievable to gain speed control by the immense range [1]. DC Motors have variable characteristics and are used extensively in variable speed drives. DC motor can provide a high starting torque and it is also possible to obtain speed control over a wide range [2].
Generally, DC motor is used in several applications like robotics and domestic appliances due to affordable cost and low complexity of control configuration for speed and torque control [3]. DC Motors are considered as the best type of motors, in view of the speed control and speed regulation. Numerous approaches are available to control the motor rotational speed and armature voltage control is one method among these methods $[4,6]$.

The DC machine by a DC power source for determining the inductance in a DC machine disables some difficulties related to traditional methods using AC source $[7,8]$.

\footnotetext{
${ }^{1}$ Department of Electrical Engineering, Quaid-e-Awam University of Engineering, Science and Technology Nawabshah, Pakistan

${ }^{2}$ Department of Automation, Beijing University of Chemical Technology, Beijing China Corresponding Author: engr.mohsinkoondhar@ quest.edu.pk
} 
Mohsin Ali (et al.), Experimental based Comparative Analysis and Characteristics of DC Series Motor by using Different Techniques

DC machines are versatile energy conversion devices. These can be used for loads of high starting torques and to meet loads of high accelerating and decelerating torques [9]. For DC motors, the armature and field current are the same because the connection between them is standard [10, 11]. Armature voltage/armature control methods can be used to control the speed of dc motor $[12,13]$.

\section{Conventional Controllers}

Speed control of a motor escape intended to replace speed render to the demand of the workload connected with the motor. This preserve if done by mechanical expedients, such as by using stepped simple machines.

Nevertheless, speed control by the electrical way has greater advantages over mechanical. In many applications, DC motor is preferred over other types of motors because DC Motors offer easy speed control.

DC Motor Speed control methods depend upon,

a. Armature Control Method and

b. Armature Voltage Control Method [14].

\subsection{Armature Control Method}

It can apply during speeds where loading speed is not required. Supply voltage usually invariable, by place a flexible rheostat in series with armature circuit, the voltage across armature may change shown in figure1.

To decrease the armature speed potential difference beyond armature is dropped by increasing the value of resistance in the controller. For load-torque, speed is closely comparative to potential difference over the armature [15].

Armature resistance control is simple for small motors while it wastes energy and unusable with large motors [16].

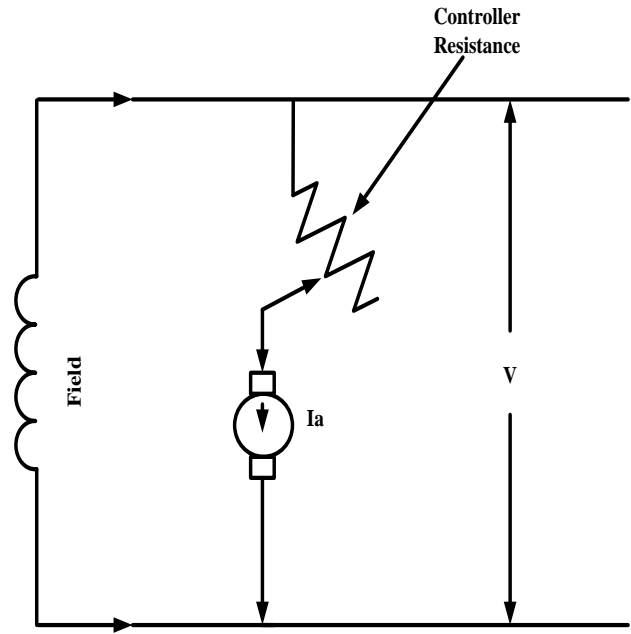

Fig 1: Armature Control Method

\subsection{Armature Voltage Control Method}

The speed of armature-controlled DC motor is controlled by armature voltage $V_{a}$ and utilizes a constant field current shown in figure 2 .

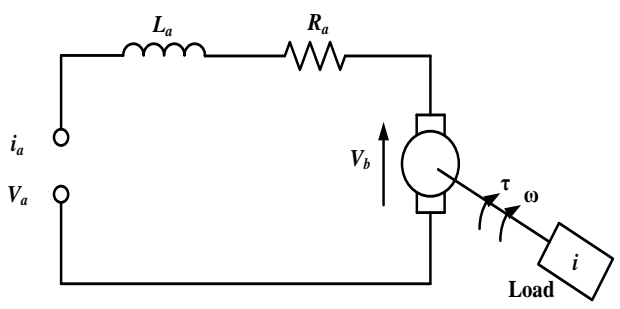

Fig 2: Armature Voltage Control Method

The armature controlled can be expressed by equations as:

$$
\begin{aligned}
& \mathrm{I} \omega=-\mathrm{b} . \omega+K_{\mathrm{t}} i_{\mathrm{a}} \mathrm{T}_{L} \\
& V_{a}-V_{b}=\mathrm{La} \frac{d i a}{d t}+R_{\mathrm{a}} \cdot i_{\mathrm{a}}
\end{aligned}
$$

Where

$$
V_{b}=K_{b} \cdot \omega
$$

In the state-space form, the equation of DC Motor is: 
$\frac{d}{d t}\left[\begin{array}{c}\omega \\ i_{a}\end{array}\right]=\left[\begin{array}{cc}-\frac{b}{I} & \frac{K_{t}}{I} \\ -\frac{R_{a}}{L_{a}} & -\frac{K_{b}}{L_{a}}\end{array}\right]\left\{\begin{array}{l}\omega \\ i_{a}\end{array}\right\}+\left[\begin{array}{c}0 \\ \frac{1}{L_{a}}\end{array}\right] \cdot V_{a}+\left[\begin{array}{c}\frac{-1}{I} \\ 0\end{array}\right] \cdot T_{L}$

\section{Programmable Logic Controller}

DC motors are one of the devices that can be connected and controlled by PLC [17]. The PLC-based control system is a microprocessor-based controller. In this, a memory specifically programmable memory is used to store the instructions and various functions. Presently Programmable Logic Controller is vastly used in industry [6]. The PLC is a functional computer employed in the machines where the control and operation of completion manner [18, 19]. It is the function of the programmable retention, accumulation guidance, and finishing including $\mathrm{ON}$ and OFF shown in figure 4.

Figure 3 shows the basic arrangement of PLC incorporated within the trainer. There are 20 I/O connectors, from which 10 for input and 10 for output, and a voltage stabilizer is used to maintain the required voltage. LED Lights Input and Output Connectors PLC

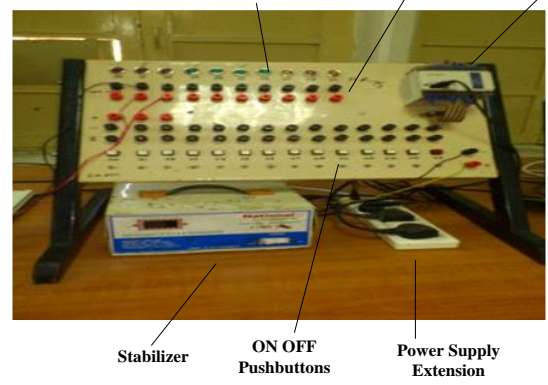

Fig 3: PLC

\section{PLC Ladder Diagram}

For ease of programming, the programmable controller is advanced by adopting existing relay ladder design and expressions to take as program logics, necessary to control the machine or process. A relay ladder diagram is shown in figure 6 .

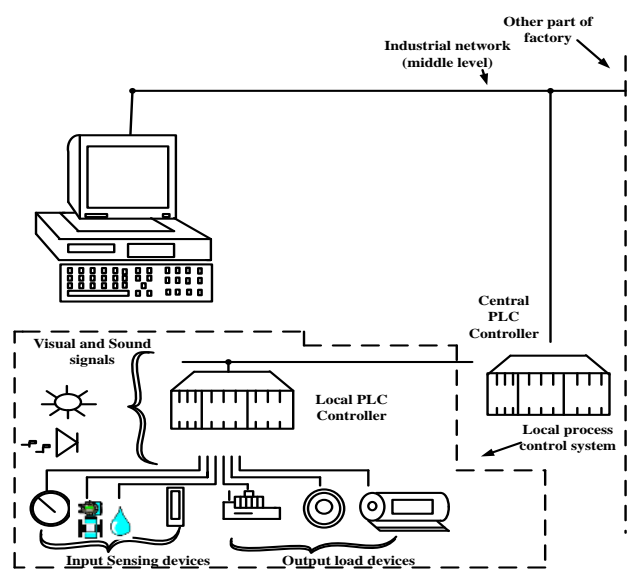

Fig 4: PLC Layout

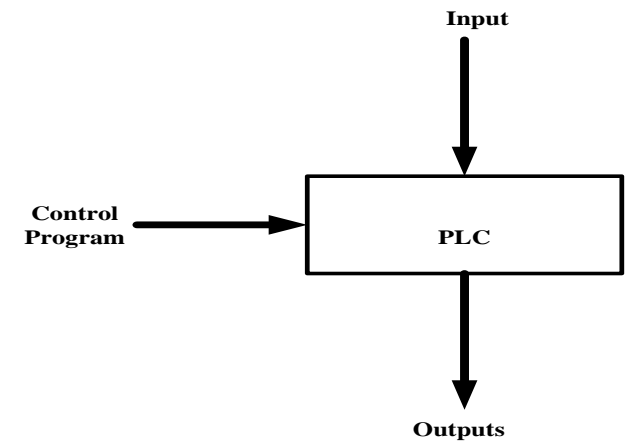

Fig 5: PLC as a Control Action

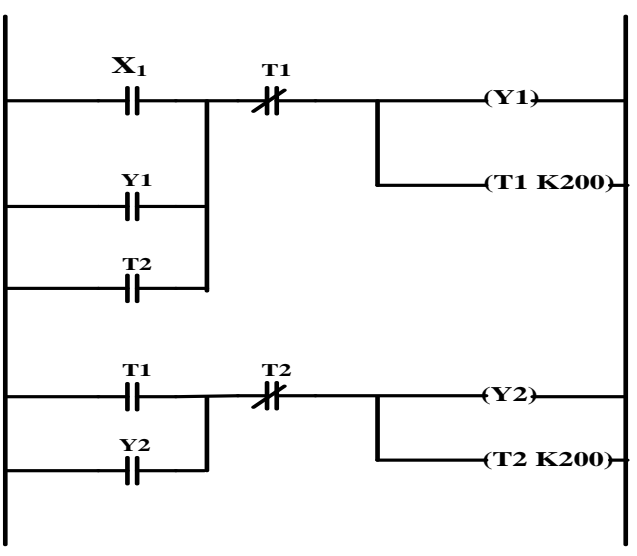

Fig 6: Ladder Diagram of a PLC 
Mohsin Ali (et al.), Experimental based Comparative Analysis and Characteristics of DC Series Motor by using Different Techniques

\subsection{Motor Characteristics with Armature Controller}

The characteristic of the motor means the determination relationship between speed, power, and current without load. Figure 7 shows the experimental setup of the dc series motor with the Armature controller.

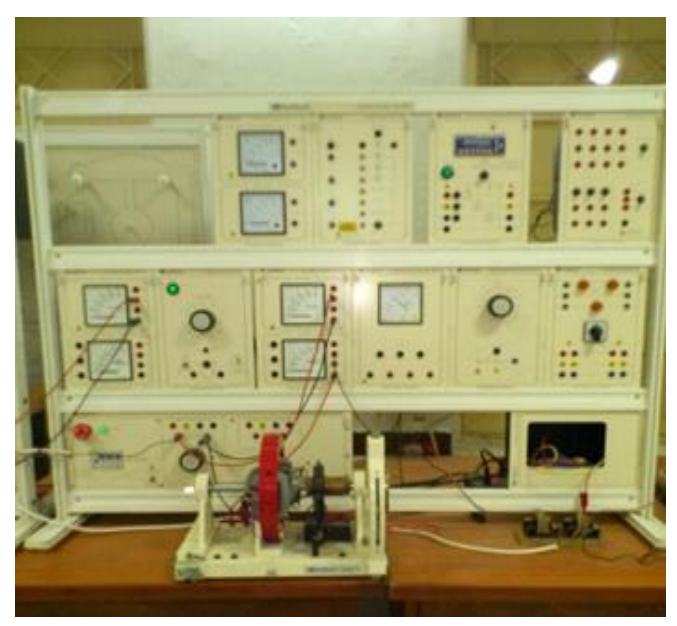

Fig 7: Experimental setup of DC Series Motor with Armature Controller

\subsubsection{Torque vs. speed characteristics of DC Motor with Armature Controller}

The characteristic result of torque vs. speed of dc series motor is presented in Table 1 and graphically present shown in figure 8 . In this table there are different levels of supply voltages are supplied and different torque are applied as a load from $0 \mathrm{Nm}$ to 1 $\mathrm{Nm}$ in equal of 1 step respectively in order to observe the effectiveness of torque on the speed of DC Motor. It is clearly mentioned in the table that if the value of torque increased from $0.1 \mathrm{Nm}$ to $1 \mathrm{Nm}$ than the speed of DC Motor decreased

Figure 8 illustrates that as supply voltages raises from 30 to 50 voltages the speed of DC series motor is increased but as torque increases simultaneously the speed of $\mathrm{dc}$ series motor decreases.

Table 1: Toque Speed Characteristics with Armature Controller

\begin{tabular}{|c|c|c|c|c|c|}
\hline \multirow{2}{*}{$\begin{array}{c}\text { Torque } \\
(\mathrm{N}-\mathrm{M})\end{array}$} & $\begin{array}{c}\mathrm{V}=30 \\
\mathrm{~V}\end{array}$ & $\begin{array}{c}\mathrm{V}=35 \\
\mathrm{~V}\end{array}$ & \multicolumn{4}{|c|}{$\begin{array}{c}\text { Armature Controller } \\
\mathrm{V}\end{array}$} & \multicolumn{5}{|c|}{$\begin{array}{c}\text { V=45 } \\
\mathrm{V}\end{array}$} & $\begin{array}{c}\text { V=50 } \\
\mathrm{V}\end{array}$ \\
\cline { 2 - 6 } & $\begin{array}{c}\text { Speed } \\
(\mathrm{RPM})\end{array}$ & $\begin{array}{c}\text { Speed } \\
(\mathrm{RPM})\end{array}$ & $\begin{array}{c}\text { Speed } \\
(\mathrm{RPM})\end{array}$ & $\begin{array}{c}\text { Speed } \\
(\mathrm{RPM})\end{array}$ & $\begin{array}{c}\text { Speed } \\
(\mathrm{RPM})\end{array}$ \\
\hline 0 & 1125 & 1440 & 1750 & 1980 & 2280 \\
\hline 0.1 & 1065 & 1380 & 1690 & 1930 & 2265 \\
\hline 0.2 & 1034 & 1336 & 1620 & 1890 & 2110 \\
\hline 0.3 & 1000 & 1278 & 1555 & 1850 & 2080 \\
\hline 0.4 & 968 & 1240 & 1510 & 1740 & 1960 \\
\hline 0.5 & 924 & 1210 & 1470 & 1680 & 1910 \\
\hline 0.6 & 886 & 1170 & 1400 & 1580 & 1703 \\
\hline 0.7 & 868 & 1135 & 1340 & 1500 & 1680 \\
\hline 0.8 & 852 & 1090 & 1290 & 1430 & 1660 \\
\hline 0.9 & 809 & 1030 & 1280 & 1370 & 1600 \\
\hline 1 & 770 & 1008 & 1222 & 1340 & 1530 \\
\hline
\end{tabular}




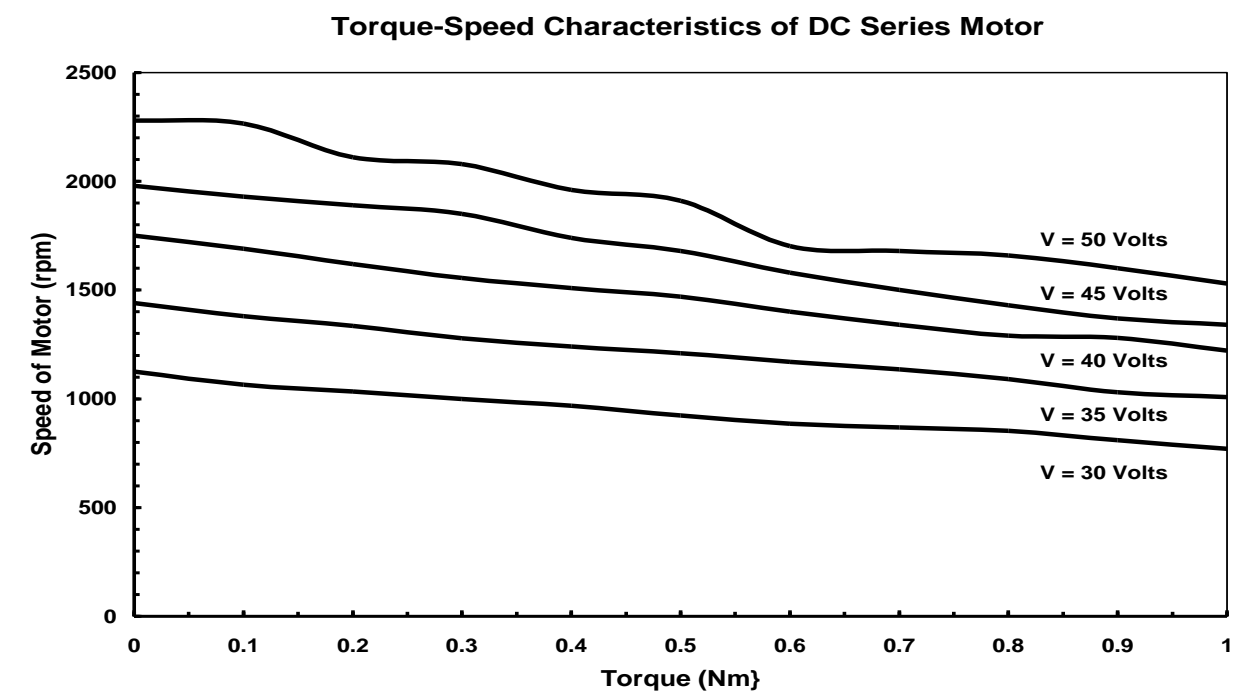

Fig 8: Torque vs. Speed characteristics of DC Series Motor

4.1.2 Torque vs. Current characteristics of supplied and different torque are applied as a DC Series Motor with Armature load from $0 \mathrm{Nm}$ to $1 \mathrm{Nm}$ in equal of 1 step Controller

Result of torque and current characteristic of DC series motor presented in table 2 and graphically present in figure 9 . In this table there are different levels of supply voltages are respectively in order to observe the effectiveness torque on the speed of DC Motor. Clearly mention in the table that if the value of torque varies from $0.1 \mathrm{~N}-\mathrm{m}$ to $1 \mathrm{~N}-\mathrm{m}$ than the speed of DC Motor decreased.

Table 2: Torque Current characteristics DC Series Motor

\begin{tabular}{|c|c|c|c|c|c|}
\hline $\begin{array}{c}\text { Torque } \\
(\mathrm{N}-\mathrm{M})\end{array}$ & $\mathrm{V}=30 \mathrm{~V}$ & $\mathrm{~V}=35 \mathrm{~V}$ & $\mathrm{~V}=40 \mathrm{~V}$ & $\mathrm{~V}=45 \mathrm{~V}$ & $\mathrm{~V}=50 \mathrm{~V}$ \\
\hline & \multicolumn{5}{|c|}{ Armature Controller } \\
\hline & Current (A) & Current $(\mathrm{A})$ & Current (A) & Current (A) & Current (A) \\
\hline 0 & 0.8 & 0.7 & 0.7 & 0.7 & 0.7 \\
\hline 0.1 & 0.8 & 0.8 & 0.8 & 0.8 & 0.8 \\
\hline 0.2 & 0.8 & 0.8 & 0.8 & 0.8 & 0.8 \\
\hline 0.3 & 0.8 & 0.9 & 0.9 & 0.9 & 0.8 \\
\hline 0.4 & 0.9 & 0.9 & 0.9 & 0.9 & 0.9 \\
\hline 0.5 & 0.9 & 0.9 & 0.9 & 0.9 & 0.9 \\
\hline 0.6 & 0.9 & 0.9 & 0.9 & 0.9 & 0.9 \\
\hline 0.7 & 1 & 1 & 1 & 1 & 1 \\
\hline 0.8 & 1 & 1 & 1 & 1 & 1 \\
\hline 0.9 & 1 & 1 & 1 & 1 & 1 \\
\hline 1 & 1 & 1 & 1 & 1 & 1 \\
\hline
\end{tabular}




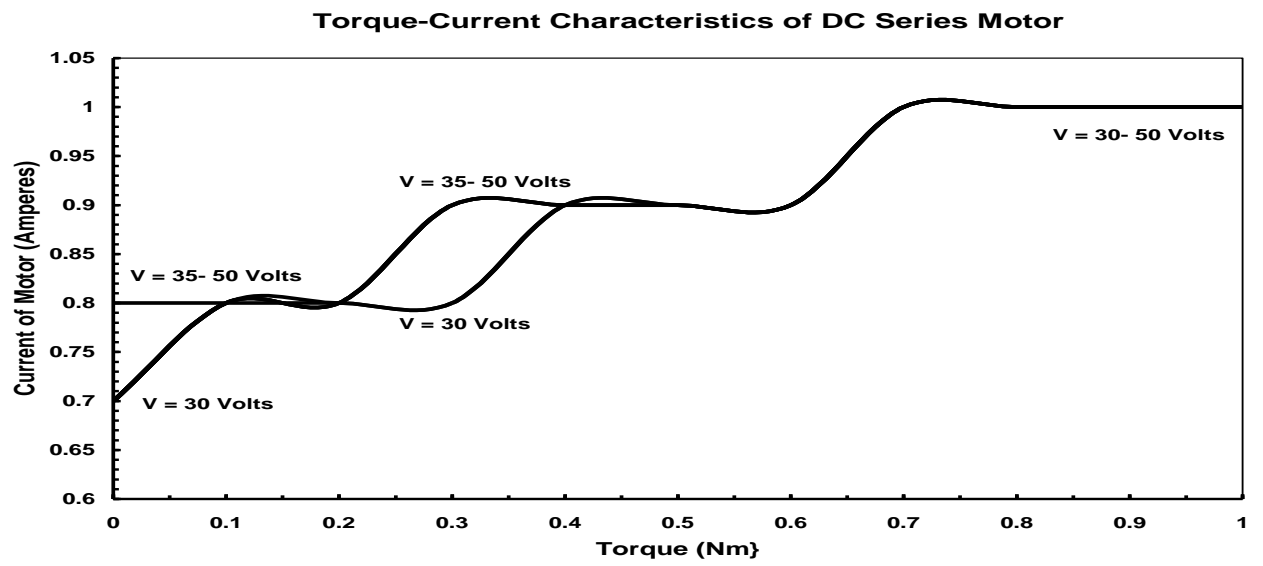

Fig 9: Torque vs. Current characteristics of DC Series Motor

\begin{abstract}
4.1.3 Torque vs. Power characteristics of DC Series Motor with Armature Controller

The characteristic result of the torque and power of DC Series Motor is presented in table 3 and graphically present shown in figure 10 . In this table there are different levels of supply

voltages are supplied and different torque are applied as a load from $0 \mathrm{Nm}$ to $1 \mathrm{Nm}$ in equal of 1 step respectively to observe the effectiveness of torque on the speed of DC Motor. Here clearly mention in the table that if the value of torque increased from $0.1 \mathrm{Nm}$ to 1 $\mathrm{Nm}$ than the speed of DC Motor decreased.
\end{abstract}

Table 3 Torque Power characteristics DC Series Motor

\begin{tabular}{|c|c|c|c|c|c|}
\hline \multirow[b]{3}{*}{ Torque (N-M) } & $\begin{array}{c}\mathrm{V}=30 \\
\mathrm{~V}\end{array}$ & $\begin{array}{c}\mathrm{V}=35 \\
\mathrm{~V}\end{array}$ & $\begin{array}{c}\mathrm{V}=40 \\
\mathrm{~V}\end{array}$ & $\begin{array}{c}\mathrm{V}=45 \\
\mathrm{~V}\end{array}$ & $\begin{array}{c}\mathrm{V}=50 \\
\mathrm{~V}\end{array}$ \\
\hline & \multicolumn{5}{|c|}{ Armature Controller } \\
\hline & $\begin{array}{l}\text { Power } \\
\text { (Watt) }\end{array}$ & $\begin{array}{l}\text { Power } \\
\text { (Watt) }\end{array}$ & $\begin{array}{l}\text { Power } \\
\text { (Watt) }\end{array}$ & $\begin{array}{l}\text { Power } \\
\text { (Watt) }\end{array}$ & $\begin{array}{l}\text { Power } \\
\text { (Watt) }\end{array}$ \\
\hline 0 & 24 & 24.5 & 28 & 31.5 & 35 \\
\hline 0.1 & 24 & 28 & 32 & 36 & 40 \\
\hline 0.2 & 24 & 28 & 32 & 36 & 40 \\
\hline 0.3 & 24 & 31.5 & 36 & 40.5 & 40 \\
\hline 0.4 & 27 & 31.5 & 36 & 40.5 & 45 \\
\hline 0.5 & 27 & 31.5 & 36 & 40.5 & 45 \\
\hline 0.6 & 27 & 31.5 & 36 & 40.5 & 45 \\
\hline 0.7 & 30 & 35 & 40 & 45 & 50 \\
\hline 0.8 & 30 & 35 & 40 & 45 & 50 \\
\hline 0.9 & 30 & 35 & 40 & 45 & 50 \\
\hline 1 & 30 & 35 & 40 & 45 & 50 \\
\hline
\end{tabular}




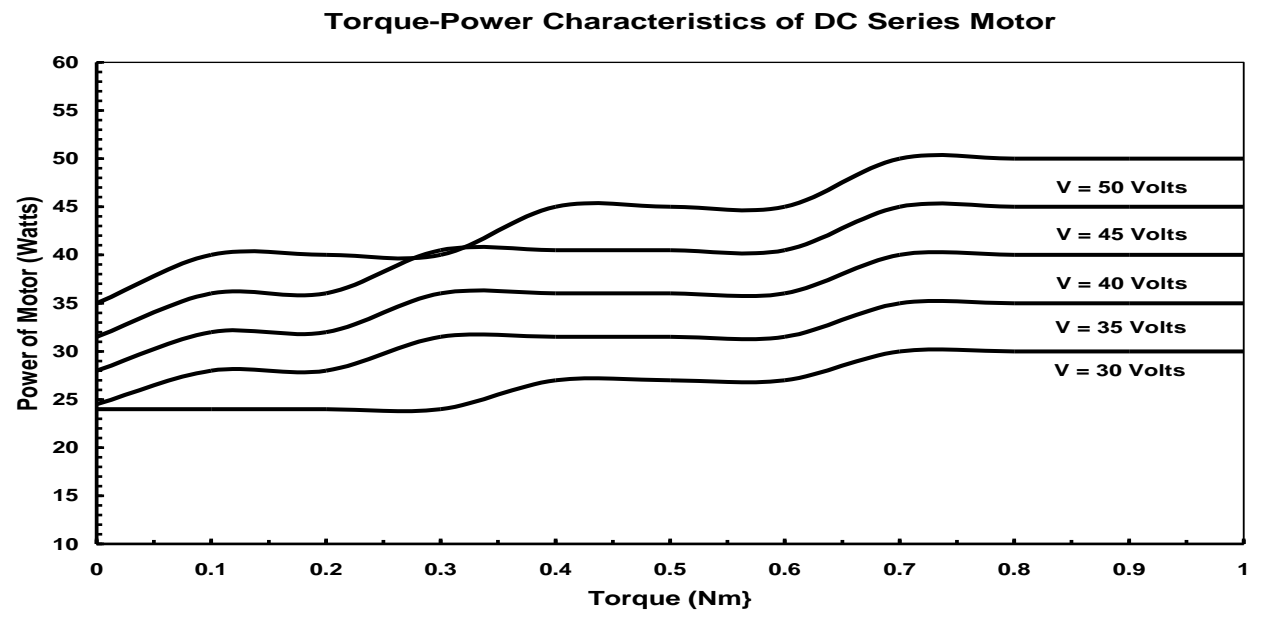

Fig 10: Torque Power characteristics of DC Series Motor

\subsection{Experimental structure of DC Series Motor with PLC}

'Experimental setup is illustrated in figure 11.

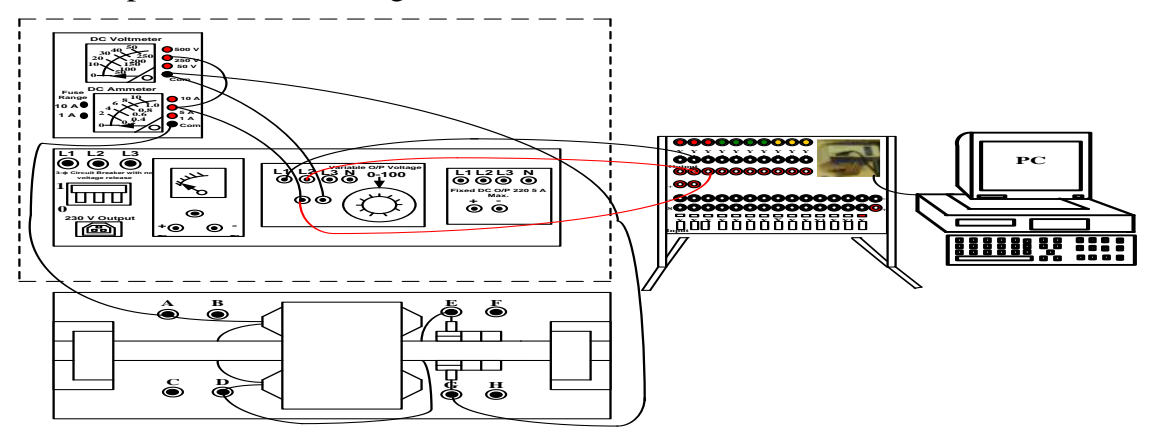

Fig 11: Experimental structure of DC Series Motor with PLC

4.2.1 DC Motor Torque vs. speed characteristics with PLC

The characteristic result of torque vs. speed of DC series motor is presented in Table 4 and graphically present shown in figure 12 . In this table there are different levels of supply voltages are supplied and different torque are applied as a load from $0 \mathrm{Nm}$ to $1 \mathrm{Nm}$ in equal of 1 step respectively to observe the effectiveness of torque on the speed of DC Motor. It's clearly mentioned in the table that if the value of torque increased from $0.1 \mathrm{Nm}$ to $1 \mathrm{Nm}$ than the speed of dc motor decreased. 
Mohsin Ali (et al.), Experimental based Comparative Analysis and Characteristics of DC Series Motor by using Different Techniques

Table 4: DC Series Motor Torque vs. Speed characteristics with PLC

\begin{tabular}{|c|c|c|c|c|c|}
\hline \multirow[b]{3}{*}{$\begin{array}{l}\text { Torque } \\
(\mathrm{N}-\mathrm{M})\end{array}$} & $\mathrm{V}=30 \mathrm{v}$ & $\mathrm{V}=35 \mathrm{v}$ & $\mathrm{V}=40 \mathrm{v}$ & $V=45 \mathrm{v}$ & $\mathrm{V}=50 \mathrm{v}$ \\
\hline & \multicolumn{5}{|c|}{ With PLC } \\
\hline & $\begin{array}{c}\text { Speed } \\
\text { (RPM) }\end{array}$ & $\begin{array}{c}\text { Speed } \\
\text { (RPM) }\end{array}$ & $\begin{array}{c}\text { Speed } \\
(\mathrm{RPM})\end{array}$ & $\begin{array}{c}\text { Speed } \\
\text { (RPM) }\end{array}$ & $\begin{array}{c}\text { Speed } \\
(\mathrm{RPM})\end{array}$ \\
\hline 0 & 1000 & 1200 & 1530 & 1736 & 1940 \\
\hline 0.1 & 982 & 1150 & 1520 & 1690 & 1700 \\
\hline 0.2 & 950 & 1130 & 1480 & 1650 & 1680 \\
\hline 0.3 & 880 & 1070 & 1320 & 1470 & 1590 \\
\hline 0.4 & 870 & 1060 & 1300 & 1460 & 1580 \\
\hline 0.5 & 850 & 978 & 1150 & 1290 & 1400 \\
\hline 0.6 & 800 & 950 & 1140 & 1230 & 1380 \\
\hline 0.7 & 670 & 900 & 1040 & 1200 & 1250 \\
\hline 0.8 & 650 & 833 & 1000 & 1100 & 1230 \\
\hline 0.9 & 630 & 820 & 935 & 1060 & 1220 \\
\hline 1 & 594 & 800 & 900 & 980 & 1150 \\
\hline
\end{tabular}

Torque-Speed Characteristics of DC Series Motor With PLC

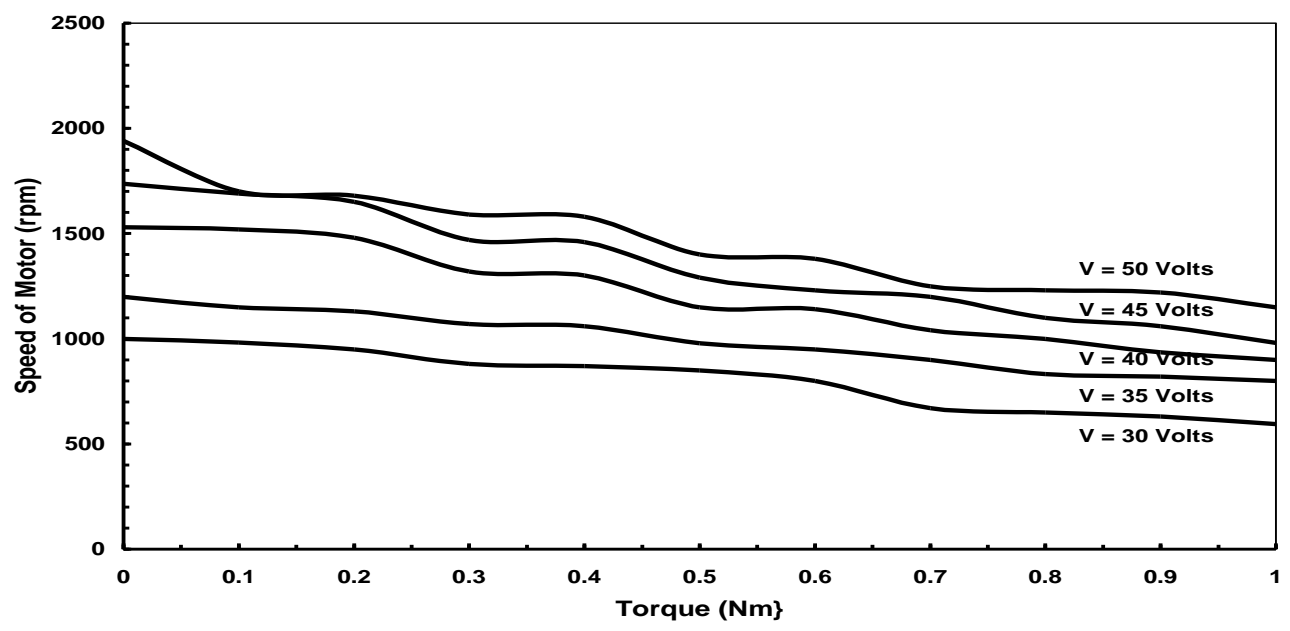

Fig 12: DC Series Motor Torque vs. Speed characteristics with PLC [5]

Torque vs. current characteristics of $\boldsymbol{D C}$ applied as a load from $0 \mathrm{Nm}$ to $1 \mathrm{Nm}$ in equal Series Motor with PLC of 1 step respectively to observe the

The characteristic result of torque and effectiveness of torque on the speed of DC current of DC series motor is presented in table Motor. It is clearly mentioned in the table that 5 and graphically present shown in figure 13 . if the value of torque varies from $0.1 \mathrm{Nm}$ to 1 In this table there are different levels of supply $\mathrm{Nm}$ than the speed of DC motor decreased. voltages are supplied and different torque are 
Mohsin Ali (et al.), Experimental based Comparative Analysis and Characteristics of DC Series Motor by using Different Techniques

Table 5: DC Series Motor Torque Current characteristics with PLC

\begin{tabular}{|c|c|c|c|c|c|}
\hline \multirow[b]{3}{*}{ Torque (N-M) } & $\mathrm{V}=30 \mathrm{v}$ & $\mathrm{V}=35 \mathrm{v}$ & $\mathrm{V}=40 \mathrm{v}$ & $\mathrm{V}=45 \mathrm{v}$ & $\mathrm{V}=50 \mathrm{v}$ \\
\hline & \multicolumn{5}{|c|}{ With PLC } \\
\hline & Current (A) & Current (A) & Current (A) & Current (A) & Current (A) \\
\hline 0 & 0.8 & 0.8 & 0.8 & 0.9 & 0.9 \\
\hline 0.1 & 0.9 & 0.9 & 0.9 & 0.9 & 0.9 \\
\hline 0.2 & 0.9 & 0.9 & 0.9 & 0.9 & 0.9 \\
\hline 0.3 & 0.9 & 0.9 & 0.9 & 0.9 & 0.9 \\
\hline 0.4 & 0.9 & 0.9 & 0.9 & 0.9 & 0.9 \\
\hline 0.5 & 1 & 1 & 1.1 & 1.1 & 1.1 \\
\hline 0.6 & 1.2 & 1 & 1.1 & 1.1 & 1.1 \\
\hline 0.7 & 1.2 & 1.2 & 1.2 & 1.2 & 1.2 \\
\hline 0.8 & 1.2 & 1.2 & 1.2 & 1.2 & 1.3 \\
\hline 0.9 & 1.2 & 1.2 & 1.2 & 1.2 & 1.3 \\
\hline 1 & 1.3 & 1.3 & 1.3 & 1.3 & 1.3 \\
\hline
\end{tabular}

Torque-Current Characteristics of DC Series Motor with PLC

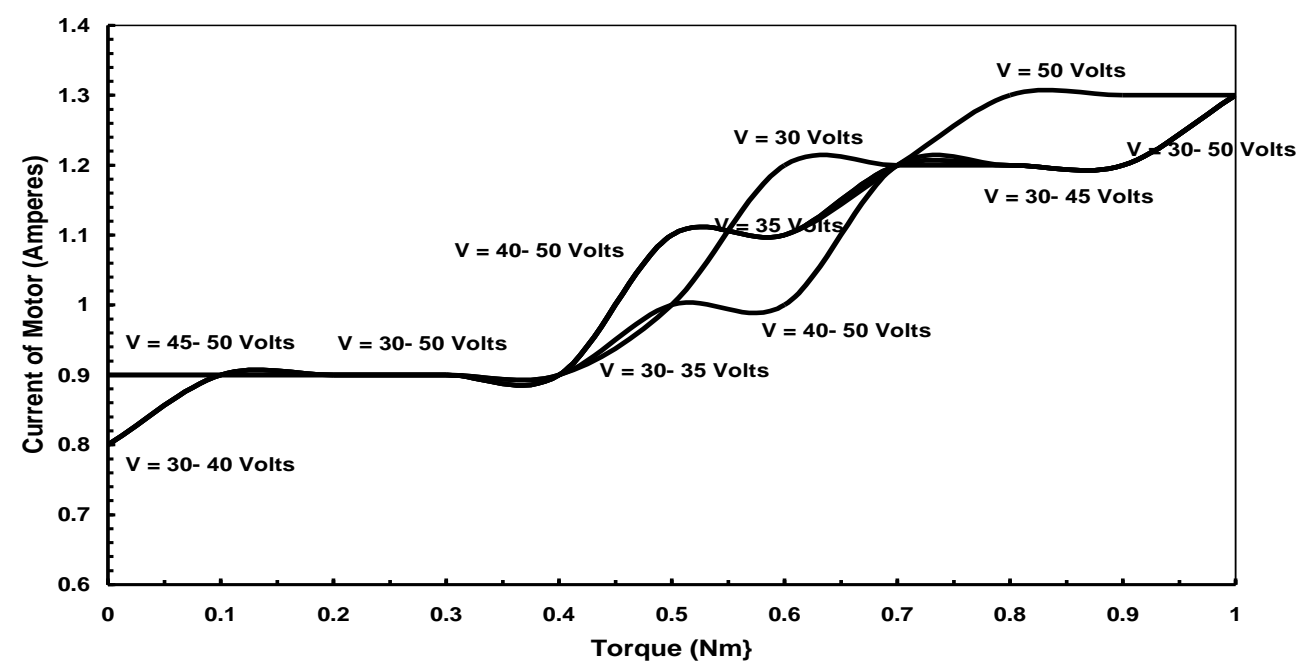

Fig 13: DC series Motor Torque vs. Current characteristics of with PLC

\subsubsection{Series Motor Torque power characteristics with PLC}

Characteristic result of torque power of DC torque on the speed of DC Motor. It is clearly series motor presented in table 6 and mentioned in the table that if the value of graphically present in figure 14 . In this table torque increased from $0.1 \mathrm{Nm}$ to $1 \mathrm{Nm}$ than the respectively to observe the effectiveness of speed of DC motor decreased 
Mohsin Ali (et al.), Experimental based Comparative Analysis and Characteristics of DC Series Motor by using Different

Table 6 Torque Power characteristics DC Series Motor with PLC

\begin{tabular}{|l|l|l|l|l|l|}
\hline \multirow{4}{*}{$\begin{array}{l}\text { Torque } \\
(\mathrm{N}-\mathrm{M})\end{array}$} & $\mathrm{V}=30 \mathrm{~V}$ & $\mathrm{~V}=35 \mathrm{~V}$ & $\mathrm{~V}=40 \mathrm{~V}$ & $\mathrm{~V}=45 \mathrm{~V}$ & $\mathrm{~V}=50 \mathrm{~V}$ \\
\cline { 2 - 6 } & \multicolumn{5}{|c|}{ With PLC } \\
\hline 0 & Power (Watt) & $\begin{array}{l}\text { Power } \\
(\text { Watt) }\end{array}$ & $\begin{array}{l}\text { Power } \\
\text { (Watt) }\end{array}$ & $\begin{array}{l}\text { Power } \\
(\text { Watt) }\end{array}$ & $\begin{array}{l}\text { Power } \\
\text { (Watt) }\end{array}$ \\
\hline 0.1 & 24 & 28 & 32 & 40.5 & 45 \\
\hline 0.2 & 27 & 31.5 & 36 & 40.5 & 45 \\
\hline 0.3 & 27 & 31.5 & 36 & 40.5 & 45 \\
\hline 0.4 & 27 & 31.5 & 36 & 40.5 & 45 \\
\hline 0.5 & 27 & 31.5 & 36 & 40.5 & 45 \\
\hline 0.6 & 30 & 35 & 44 & 49.5 & 55 \\
\hline 0.7 & 36 & 35 & 44 & 49.5 & 55 \\
\hline 0.8 & 36 & 42 & 48 & 54 & 60 \\
\hline 0.9 & 36 & 42 & 48 & 54 & 65 \\
\hline 1 & 39 & 42 & 48 & 54 & 65 \\
\hline
\end{tabular}

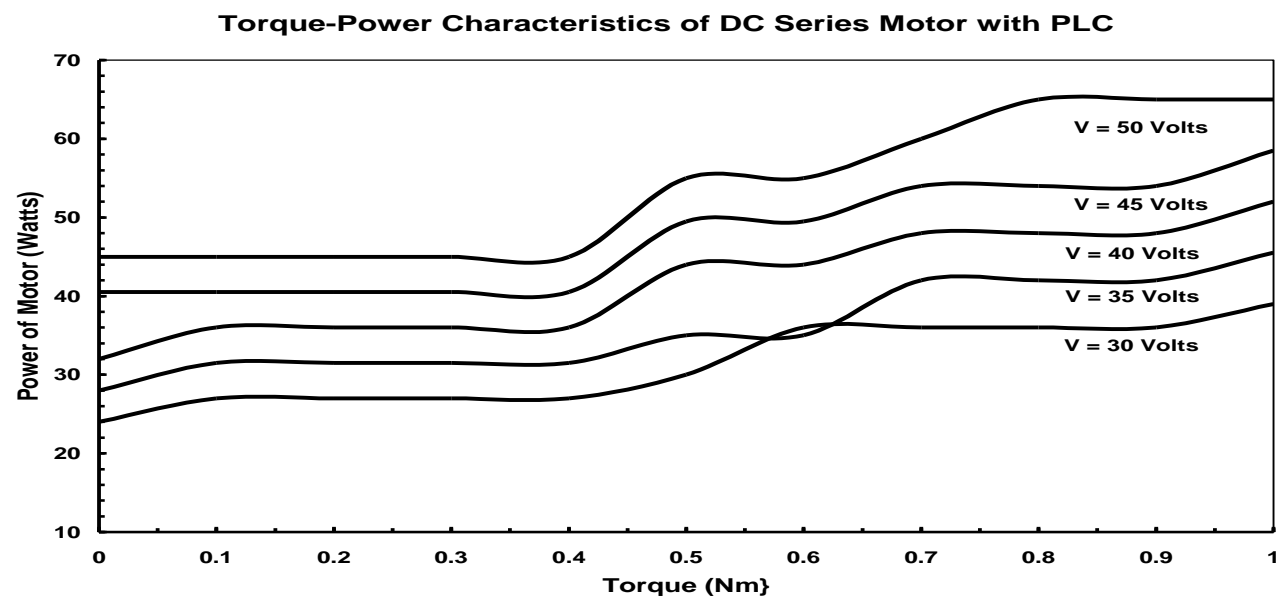

Fig14: DC Series Motor Torque vs. Power characteristics with PLC 
Mohsin Ali (et al.), Experimental based Comparative Analysis and Characteristics of DC Series Motor by using Different Techniques

(pp. $1-15)$

Table 7 Comparison of Torque Speed characteristics DC Series Motor PLC with Armature Controller

\begin{tabular}{|c|c|c|c|c|c|c|c|c|c|c|}
\hline \multirow[b]{3}{*}{$\begin{array}{l}\text { Torqu } \\
\text { e (N } \\
. \mathrm{m})\end{array}$} & \multicolumn{10}{|c|}{ Speed (rpm) } \\
\hline & \multicolumn{2}{|c|}{$\mathrm{V}=30 \mathrm{v}$} & \multicolumn{2}{|c|}{$\mathrm{V}=35 \mathrm{v}$} & \multicolumn{2}{|c|}{$\mathrm{V}=40 \mathrm{v}$} & \multicolumn{2}{|c|}{$\mathrm{V}=45 \mathrm{v}$} & \multicolumn{2}{|c|}{$\mathrm{V}=50 \mathrm{v}$} \\
\hline & $\begin{array}{l}\text { Witho } \\
\text { ut PLC }\end{array}$ & $\begin{array}{c}\text { Wit } \\
\text { h } \\
\text { PL } \\
\text { C }\end{array}$ & $\begin{array}{l}\text { Witho } \\
\text { ut PLC }\end{array}$ & $\begin{array}{c}\text { Wit } \\
\text { h } \\
\text { PL } \\
\text { C }\end{array}$ & $\begin{array}{l}\text { Witho } \\
\text { ut PLC }\end{array}$ & $\begin{array}{c}\text { Wit } \\
\text { h } \\
\text { PL } \\
\text { C }\end{array}$ & $\begin{array}{l}\text { Witho } \\
\text { ut PLC }\end{array}$ & $\begin{array}{c}\text { Wit } \\
\text { h } \\
\text { PL } \\
\text { C }\end{array}$ & $\begin{array}{l}\text { Witho } \\
\text { ut PLC }\end{array}$ & $\begin{array}{c}\text { Wit } \\
\text { h } \\
\text { PL } \\
\text { C }\end{array}$ \\
\hline 0 & 1125 & $\begin{array}{c}100 \\
0\end{array}$ & 1440 & $\begin{array}{c}120 \\
0\end{array}$ & 1750 & $\begin{array}{c}153 \\
0\end{array}$ & 1980 & $\begin{array}{c}173 \\
6\end{array}$ & 2280 & $\begin{array}{c}194 \\
0\end{array}$ \\
\hline 0.1 & 1065 & 982 & 1380 & $\begin{array}{c}115 \\
0\end{array}$ & 1690 & $\begin{array}{c}152 \\
0\end{array}$ & 1930 & $\begin{array}{c}169 \\
0\end{array}$ & 2265 & $\begin{array}{c}170 \\
0\end{array}$ \\
\hline 0.2 & 1034 & 950 & 1336 & $\begin{array}{c}113 \\
0\end{array}$ & 1620 & $\begin{array}{c}148 \\
0\end{array}$ & 1890 & $\begin{array}{c}165 \\
0\end{array}$ & 2110 & $\begin{array}{c}168 \\
0\end{array}$ \\
\hline 0.3 & 1000 & 880 & 1278 & $\begin{array}{c}107 \\
0\end{array}$ & 1555 & $\begin{array}{c}132 \\
0\end{array}$ & 1850 & $\begin{array}{c}147 \\
0\end{array}$ & 2080 & $\begin{array}{c}159 \\
0\end{array}$ \\
\hline 0.4 & 968 & 870 & 1240 & $\begin{array}{c}106 \\
0\end{array}$ & 1510 & $\begin{array}{c}130 \\
0\end{array}$ & 1740 & $\begin{array}{c}146 \\
0\end{array}$ & 1960 & $\begin{array}{c}158 \\
0\end{array}$ \\
\hline 0.5 & 924 & 850 & 1210 & 978 & 1470 & $\begin{array}{c}115 \\
0\end{array}$ & 1680 & $\begin{array}{c}129 \\
0\end{array}$ & 1910 & $\begin{array}{c}140 \\
0\end{array}$ \\
\hline 0.6 & 886 & 800 & 1170 & 950 & 1400 & $\begin{array}{c}114 \\
0 \\
\end{array}$ & 1580 & $\begin{array}{c}123 \\
0 \\
\end{array}$ & 1703 & $\begin{array}{c}138 \\
0 \\
\end{array}$ \\
\hline 0.7 & 868 & 670 & 1135 & 900 & 1340 & $\begin{array}{c}104 \\
0\end{array}$ & 1500 & $\begin{array}{c}120 \\
0\end{array}$ & 1680 & $\begin{array}{c}125 \\
0\end{array}$ \\
\hline 0.8 & 852 & 650 & 1090 & 833 & 1290 & $\begin{array}{c}100 \\
0\end{array}$ & 1430 & $\begin{array}{c}110 \\
0\end{array}$ & 1660 & $\begin{array}{c}123 \\
0\end{array}$ \\
\hline 0.9 & 809 & 630 & 1030 & 820 & 1280 & 935 & 1370 & $\begin{array}{c}106 \\
0 \\
\end{array}$ & 1600 & $\begin{array}{c}122 \\
0\end{array}$ \\
\hline 1 & 770 & 594 & 1008 & 800 & 1222 & 900 & 1340 & 980 & 1530 & $\begin{array}{c}115 \\
0\end{array}$ \\
\hline
\end{tabular}

4.3 Characteristics comparison of DC Series Motor with PLC and Armature Controller

\subsubsection{Comparison Torque vs. speed characteristics of DC Series Motor with PLC and Armature Controller}

A comparison between PLC and armature controller here is presented.

A comparison between torque and speed are shown in table 7 and graphically represented in figure 15. 
Mohsin Ali (et al.), Experimental based Comparative Analysis and Characteristics of DC Series Motor by using Different Techniques

(pp. 1 - 15)

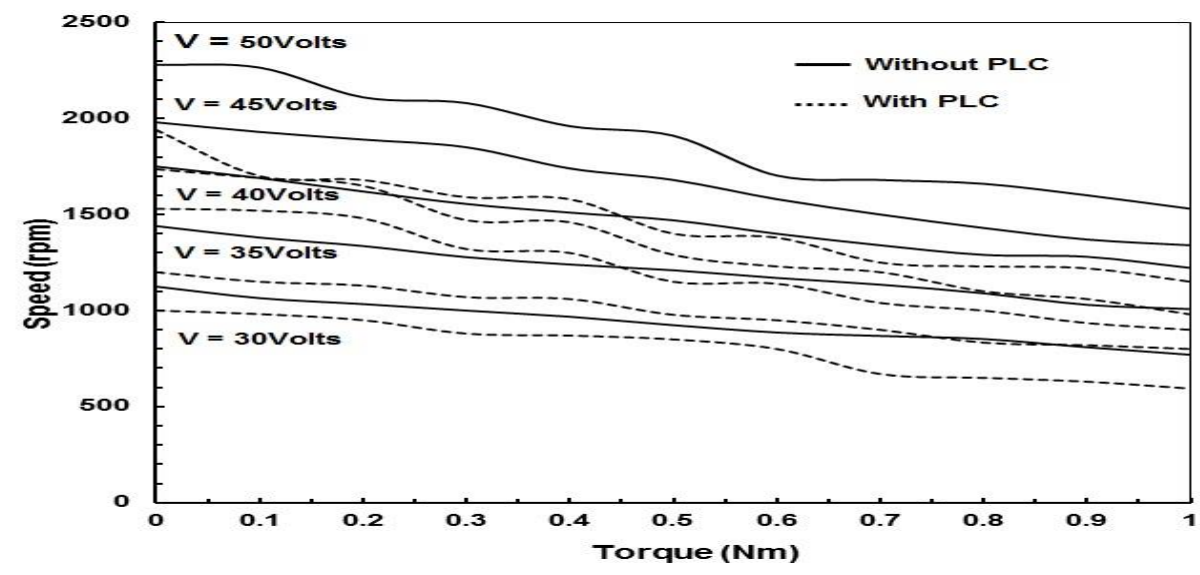

Fig 15: Graphically representation of Torque and Speed of DC Series motor with PLC and Armature controller [5].

\subsubsection{Characteristics Comparison of Torque vs. current of DC Series Motor with PLC and Armature Controller}

Comparison between torque and current are shown in table 8 and graphically represented in figure 16.

Table 8 Comparison of Torque Current characteristics DC Series Motor PLC with Armature Controller

\begin{tabular}{|c|c|c|c|c|c|c|c|c|c|c|}
\hline \multirow[b]{3}{*}{$\begin{array}{l}\text { Torqu } \\
\mathrm{e} \\
\text { (NM) }\end{array}$} & \multicolumn{10}{|c|}{ Current (Ampere) } \\
\hline & \multicolumn{2}{|c|}{$\mathrm{V}=30 \mathrm{v}$} & \multicolumn{2}{|c|}{$\mathrm{V}=35 \mathrm{v}$} & \multicolumn{2}{|c|}{$\mathrm{V}=40 \mathrm{v}$} & \multicolumn{2}{|c|}{$\mathrm{V}=45 \mathrm{v}$} & \multicolumn{2}{|c|}{$\mathrm{V}=50 \mathrm{v}$} \\
\hline & $\begin{array}{l}\text { Witho } \\
\text { ut } \\
\text { PLC }\end{array}$ & $\begin{array}{l}\text { With } \\
\text { PLC }\end{array}$ & $\begin{array}{c}\text { Witho } \\
\text { ut } \\
\text { PLC }\end{array}$ & $\begin{array}{l}\text { With } \\
\text { PLC }\end{array}$ & $\begin{array}{l}\text { Witho } \\
\text { ut } \\
\text { PLC }\end{array}$ & $\begin{array}{l}\text { With } \\
\text { PLC }\end{array}$ & $\begin{array}{l}\text { Witho } \\
\text { ut } \\
\text { PLC }\end{array}$ & $\begin{array}{l}\text { With } \\
\text { PLC }\end{array}$ & $\begin{array}{l}\text { Witho } \\
\text { ut } \\
\text { PLC }\end{array}$ & $\begin{array}{l}\text { With } \\
\text { PLC }\end{array}$ \\
\hline 0 & 0.8 & 0.8 & 0.7 & 0.8 & 0.7 & 0.8 & 0.7 & 0.9 & 0.7 & 0.9 \\
\hline 0.1 & 0.8 & 0.9 & 0.8 & 0.9 & 0.8 & 0.9 & 0.8 & 0.9 & 0.8 & 0.9 \\
\hline 0.2 & 0.8 & 0.9 & 0.8 & 0.9 & 0.8 & 0.9 & 0.8 & 0.9 & 0.8 & 0.9 \\
\hline 0.3 & 0.8 & 0.9 & 0.9 & 0.9 & 0.9 & 0.9 & 0.9 & 0.9 & 0.8 & 0.9 \\
\hline 0.4 & 0.9 & 0.9 & 0.9 & 0.9 & 0.9 & 0.9 & 0.9 & 0.9 & 0.9 & 0.9 \\
\hline 0.5 & 0.9 & 1 & 0.9 & 1 & 0.9 & 1.1 & 0.9 & 1.1 & 0.9 & 1.1 \\
\hline 0.6 & 0.9 & 1.2 & 0.9 & 1 & 0.9 & 1.1 & 0.9 & 1.1 & 0.9 & 1.1 \\
\hline 0.7 & 1 & 1.2 & 1 & 1.2 & 1 & 1.2 & 1 & 1.2 & 1 & 1.2 \\
\hline 0.8 & 1 & 1.2 & 1 & 1.2 & 1 & 1.2 & 1 & 1.2 & 1 & 1.3 \\
\hline 0.9 & 1 & 1.2 & 1 & 1.2 & 1 & 1.2 & 1 & 1.2 & 1 & 1.3 \\
\hline 1 & 1 & 1.3 & 1 & 1.3 & 1 & 1.3 & 1 & 1.3 & 1 & 1.3 \\
\hline
\end{tabular}




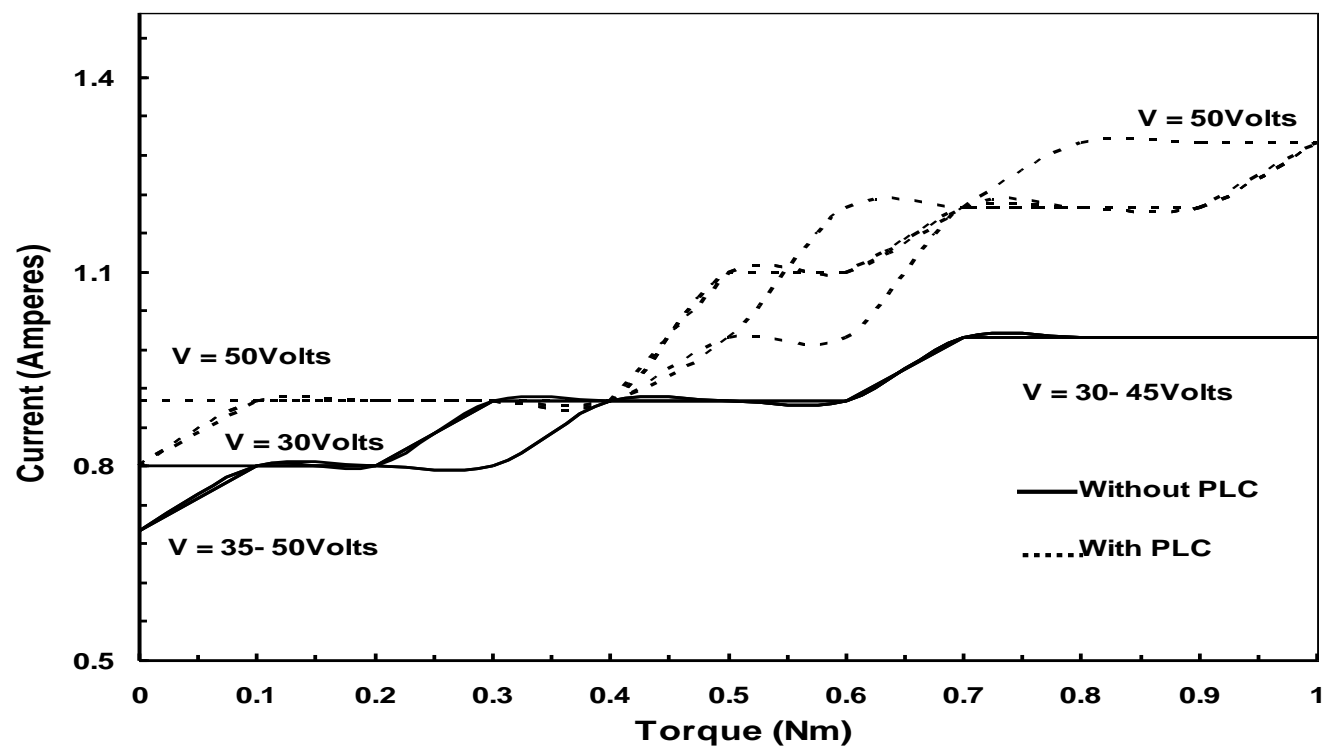

Fig 16: Graphically representation of Torque and Current of DC Series motor with PLC and Armature controller

\subsubsection{Comparison Torque power characteristics of DC Series Motor with PLC and Armature Controller}

Comparison between torque and current are shown in table 9 and graphically represented in figure 17.

Table 9 Comparison of Torque Power characteristics DC Series Motor PLC with Armature

Controller

\begin{tabular}{|c|c|c|c|c|c|c|c|c|c|c|}
\hline \multirow[b]{3}{*}{$\begin{array}{l}\text { Torque } \\
(\mathrm{N}-\mathrm{M})\end{array}$} & \multicolumn{10}{|c|}{ Power } \\
\hline & \multicolumn{2}{|c|}{$\mathrm{V}=30 \mathrm{v}$} & \multicolumn{2}{|c|}{$\mathrm{V}=35 \mathrm{v}$} & \multicolumn{2}{|c|}{$\mathrm{V}=40 \mathrm{v}$} & \multicolumn{2}{|c|}{$\mathrm{V}=45 \mathrm{v}$} & \multicolumn{2}{|c|}{$\mathrm{V}=50 \mathrm{v}$} \\
\hline & $\begin{array}{l}\text { Witho } \\
\text { ut } \\
\text { PLC }\end{array}$ & $\begin{array}{l}\text { With } \\
\text { PLC }\end{array}$ & $\begin{array}{l}\text { Witho } \\
\text { ut } \\
\text { PLC }\end{array}$ & $\begin{array}{l}\text { With } \\
\text { PLC }\end{array}$ & $\begin{array}{l}\text { Witho } \\
\text { ut } \\
\text { PLC }\end{array}$ & $\begin{array}{l}\text { With } \\
\text { PLC }\end{array}$ & $\begin{array}{l}\text { Witho } \\
\text { ut } \\
\text { PLC }\end{array}$ & $\begin{array}{l}\text { With } \\
\text { PLC }\end{array}$ & $\begin{array}{l}\text { Witho } \\
\text { ut } \\
\text { PLC }\end{array}$ & $\begin{array}{l}\text { With } \\
\text { PLC }\end{array}$ \\
\hline 0 & 24 & 24 & 24.5 & 28 & 28 & 32 & 31.5 & 40.5 & 35 & 45 \\
\hline 0.1 & 24 & 27 & 28 & 31.5 & 32 & 36 & 36 & 40.5 & 40 & 45 \\
\hline 0.2 & 24 & 27 & 28 & 31.5 & 32 & 36 & 36 & 40.5 & 40 & 45 \\
\hline 0.3 & 24 & 27 & 31.5 & 31.5 & 36 & 36 & 40.5 & 40.5 & 40 & 45 \\
\hline 0.4 & 27 & 27 & 31.5 & 31.5 & 36 & 36 & 40.5 & 40.5 & 45 & 45 \\
\hline 0.5 & 27 & 30 & 31.5 & 35 & 36 & 44 & 40.5 & 49.5 & 45 & 55 \\
\hline 0.6 & 27 & 36 & 31.5 & 35 & 36 & 44 & 40.5 & 49.5 & 45 & 55 \\
\hline 0.7 & 30 & 36 & 35 & 42 & 40 & 48 & 45 & 54 & 50 & 60 \\
\hline 0.8 & 30 & 36 & 35 & 42 & 40 & 48 & 45 & 54 & 50 & 65 \\
\hline 0.9 & 30 & 36 & 35 & 42 & 40 & 48 & 45 & 54 & 50 & 65 \\
\hline 1 & 30 & 39 & 35 & 45.5 & 40 & 52 & 45 & 58.5 & 50 & 65 \\
\hline
\end{tabular}




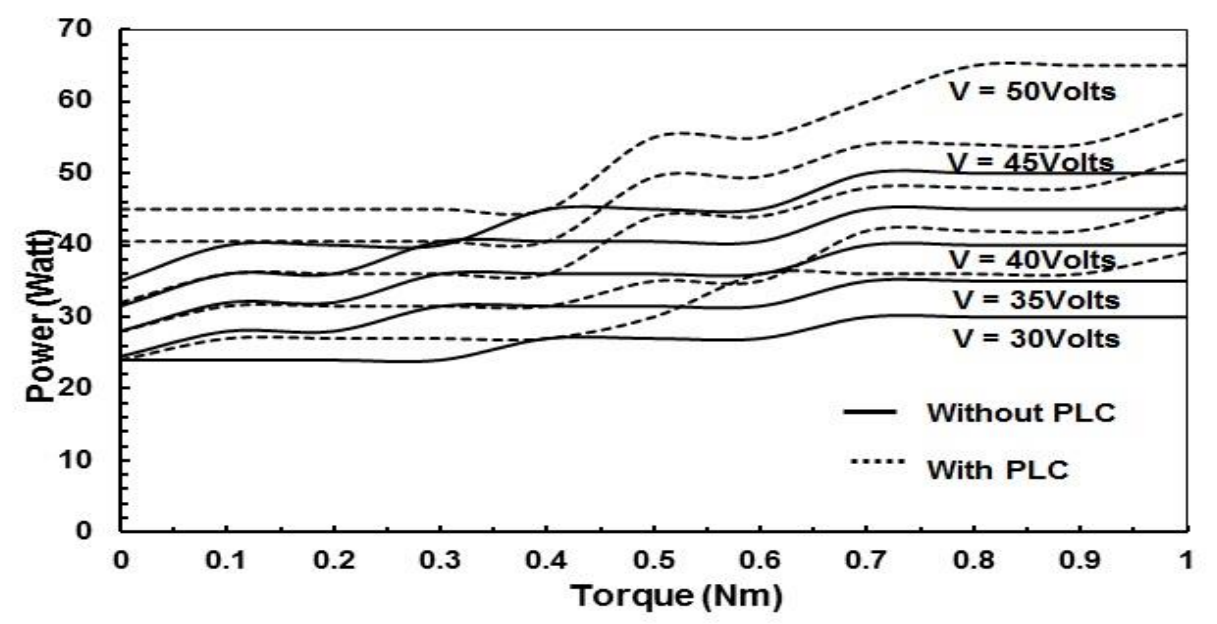

Fig 17: Graphically representation of Torque and Power of DC Series motor with PLC and Armature controller.

Figure 17 represents the relationship between power with respect to torque with and without PLC. At different voltages from 30 to $50 \mathrm{~V}$ as

\section{Conclusion and Future Work}

In this paper, the characteristics results of DC Series Motor have been obtained by using different controller techniques such as PLC and Armature controllers. In the above results and discussion, it can be easily understood that the best results are obtained by using PLC as compare to the armature controller.

By this research work, speed and torque of DC Motor can be controlled for laboratories and industrial applications.

This work can be further enhanced in the future in the following ways.

- It can be applied in industry.

- It is also used in an educational institute.

- An adaptive controller can be used for Motor control.

- Combined controlling techniques with PLC can be used to observe torque vs. speed characteristics. torque gradually increases from $0 \mathrm{NM}$ to $1 \mathrm{NM}$ power is increased.

- Matlab based Motor can be simulated for power drives and medical appliances.

\section{References}

[1] P. Malviya and M. Dubey, 2015, "Speed control of DC Motor a Review", International Journal of Engineering Sciences and Research Technology, 4(8), pages 298-305.

[2] N. Tripathi, R. Singh and R. yadav, 2015, "Analysis of Speed Control of DC Motor -A review study", International Research Journal of Engineering and Technology, 2(8).

[3] S. B. Kumar, M. H. Ali and A. Sinha, 2014, "Design and Simulation of Speed Control of DC Motor by Artificial Neural Network Technique", International Journal of Scientific and Research Publications, 4(7).

[4] M. A. Koondhar, A. K. Junejo, A. S. Saand, and M. U. Keerio, 2016, "Speed Control of DC Series Motor with Conventional and PLC Techniques", International Journal of Information Technology and Electrical Engineering, 4(5), pages 21-26.

[5] Koondhar, M.A, "Speed and Torque control of DC Series Motor by using PLC", Master Thesis, 2016. 
[6] V. Naveen and T. B. Isha, 2017 " A low cost speed estimation technique for closed loop control of BLDC motor drive", IEEE International Conference on Circuit, Power and Computing Technologies (ICCPCT), April 2017, pages 1-5.

[7] S. S. Keream, K.G. Mohammed and M.S. Ibrahim, 2018, "Analysis Study In Principles of Operation of DC Machine", Journal of Advance Research in Dynamical and Control Systems, 10(2), pages 2323-2329.

[8] N. Chuang, T. J. Gale, and R. A. Langman, 2016, "Developing measuring inductance strategies on a direct current machine using a DC source with magnetic saturation", International Journal of Circuit Theory and Applications, 44, pages 1094-1111.

[9] D. Rajesh and D. Ravikumar, S.K.Bharadwaj and B. K. S. Vastav, 2016, "Design and Control of Digital DC Drives in Steel Rolling Mills", IEEE International Conference on Inventive Computing Technologies, 3, pages 1-5.

[10] H. T. H. Thabet and M. A. Qasim, 2016, "Measurement of a DC Series Motor Torque Based on PLC Techniques" Kufa Journal of Engineering, 7(1), pages 93-103.

[11] N. K. Nambisan and B. N. Sarkar, 2014, "Study of speed control of DC series motor using DC chopper". International Journal of Advanced Research in Electrical, Electronics and Instrumentation Engineering, 3(8), pages 11116-11123.

[12] A. Mohammad and S. B. Billah, 2015, "Analysis of speed control of series DC motor using diverter and observation of speed saturation point", International Conference on Electrical Engineering and Information Communication Technology, May 2015, pages $1-4$.
[13] Mehta, V. K., and Mehta, R. (2008). Principle of electrical Machines. S. Chand.

[14] R. Rudra and R. Banerjee, 2017, “ Modeling and Simulation of DC Motor Speed Regulation by Field Current Control Using MATLAB”, International Journal of Computer Electrical Engineering, 2(9), pages 502-512.

[15] B. L. Theraia and A. K. Theraia, 2017. Textbook of Electrical Technologv Volume I, In SI System of Units. S. Chand, 2017.

[16] H. F. Frayyeh, M. A. Mukhlif, A.M. Abbood and S. S. Keream, 2019, "Speed control of direct current motor using Mechanical Characteristics", Journal of Southwest Jiaotong University, 54(4).

[17] M.S. Saleh, K. G. Mohammed, Z.S. Al-Sagar and A. Z. Sameen, 2018, "Design and Implementation of PLC-Based Monitoring and Sequence Controller System", Journal of Advance Research in Dynamical and Control Systems, 10(2), pages 2281-2289.

[18] J. R. Monfared, M. Fazeli and Y. Lotfi, 2015, "Design and PLC implementation for speed control of DC Motor using Fuzzy Logic". Journal of Electrical andComputer Engineering Innovations, 3(2), pages 71-75.

[19] L. Guo P. Pecen, 2008, "Design projects in a programmable logic controller (PLC) course in electrical engineering technology", In American Society for Engineering Education, 1(10), pages 1-10.

[20] K. Venkateswarlu and C. Chengaiah, 2014, "Comparative study on DC motor speed control using various controllers", Global Journal of Research In Engineering.

[21] S. Sharma, S. S. Oberoi and S. Nair, 2014. "Speed Control Method OF DC series motor", International Journal of Innovative Research in Technology, 1(6), pages 14501453. 